\title{
高校生にレーザーの面白さと夢を
}

\author{
村原 正隆*
}

\section{Colorful Dreams on Laser to High School Students}

\author{
Masataka MURAHARA*
}

「アンモニアガスに電波を当てると正確に振動するのです」. 私が高校3年生, 昭和 32 年の春, レーザーが誕生する 3 年前 の事だった。母校都立千才高校に,おそらく進学指導の一環として呼ばれて来たのだろう．3年生全員が講堂に集められ, 東 京工大で助手をしているという先輩の話を聞かされた。自信満々で話をするあの真っ赤な顔が今でも忘れられない. よ し大学に入ったら“化学”を勉強するぞ!でも入ったのは数学科だった。そんな時, 父が高島屋デパートで行われていたイ ベントに連れてってくれた. $10 \mathrm{~m}$ 先の風船に赤い光が当たると,“パーン”といって割れる. 待っこと5分，また光が照射さ れて,パーン。大きな装置のある場所に入り込んでいって,係りの人に怒られた。これが私の最初のレーザーとの出会い だった。私の心はまたしても“化学”か“電気”かに大きく摇れた，それがいつのまにか, 鉱山学を学んでいた。 そんな時, 米 国政府から文部省に返還された原爆投下直後の広島, 長崎の環境調查記録 $16 \mathrm{~mm}$ フィルムが昭和43年4月NHK TVで放映さ れた。広島市内の歩道に敷き詰められた御影石。これを調査員がハンマーで軽く吒くと,表面が簡単に剥がれてしまう。 ダイヤモンドカッターでも切断困難な御影石が原爆の輻射線で簡単に脆く成ってしまう。そうだ,レーザーを使えば, 岩 石が割れるかも知れない．忘れていた浪人時代のデパートでの記憶が走馬灯の如く脳裏をよざった。昭和 43 年 5 月, 好運 にも御影石の主成分 $\mathrm{SiO}_{2}$ の赤外吸収が $\mathrm{CO}_{2}$ レーザーの発振波長と等しい $10 \mu \mathrm{m}$ 帯にあることをつきとめた.Patelの論文に よると, $\mathrm{CO}_{2}$ レーザー装置の構造は簡単である.さっっく出入りの業者に放電管と言って外径 $8 \mathrm{~cm}^{\phi}$, 長さ $3 \mathrm{~m}$ の゚イイック 久製二重管を8万円で作ってもらった．共振器部は，工作室に通い旋盤と取り組んだ。電源は柱上トランスを入力と出力 を逆接続して使った．ミラーが最も大変だった。職業別電話帳でレンズ加工業を探しては一件一件訪ね歩いた。しかし,ど こもそんな長焦点ミラーを作る皿を持っていないと言って断られた。最後にたどり着いたのが横浜根岸の岡本光学だっ た。“予算がないんだろう。ある時払いの催促なしだ”と言って, 石英製金蒸着ミラーを作ってくれた。当時の出力ミラー の中心にはカップリングのための穴が空いていた。 その出力取り出し悹として, 防衛庁1研の藤沢室長のところに行って 蒷ってきた $\mathrm{NaCl}$ 板のかけらを,エーテルを用い, 眠くなる目をこらえながら透明になるまで磨き, 取り付けた，当時は光 軸調整用のHe-Neレーザーも無かった．カップリングの穴から瞀いた瞳が後部ミラーから反射してくる瞳に合わせて光軸 調整を行った。ここで初めて, 高電圧を印加することができた。電極近くのミラーの調整ねじを微調する, 正に命がけの 光軸調整だ。気が付いたら, 私の作業着のポケットが燃えていた。レーザー発振の瞬間！あんなに嬉しかった事は無い. あれから28年. その間, 理研の豊田主任研究員との出会いがエキシマレーザーとの出会いに繋がった。最初の成功がメ夕 ンガスと酸素の混合ガス䨌囲気で $\mathrm{F}_{2}$ レーザーを照射して,アルコールを生成したことであった，その後,接着不可能と言 われていたテフロンもエポキシ樹脂の有する化学種をレーザーで置換して,強接着を可能にした。 これらは正に化学であっ た. 高校時代夢見た“化学”が光化学となって私の前に戻ってきたのだ.

冒頭で述べた高校の先輩の講演は, 今から考えると抢そらくタウンズのメーザーの話であったのだろう，そんな最先端 の話とも知らず,我々高校生は彼の熱弁を化学の面白さとして聞いていた。でもこんな感動を今の高校生は味わっている だろうか. 少なくとも私の高校の頃は, マスコミは新時代のキーワードを強制しなかった．環境, 情報, 福祉, IT. だから 僕たちは“不思議”な事に胸がときめき,それを自分の手で掴もうとした。ところが現在は? 大学でオープンキャンパスを 行なうと,マスコミの流行語の付いた学科に受験生が集まる。キーワードを上辺だけしか知らないくせに, それが自分の 進むべき道だと思い込んでいる，思い込んでやって来る受験生に“君にとってもっと面白い進路があるよ”と教えること は不可能に近い。もう少し早い時期に, 彼らに情熱を語りかけなければならない。それが将来国を作る力に育つのたから. 大学で研究している若い先生, 企業で最先端技術を研究開発している若いエンジニアー諸君, 君たちの出身高校に行って, 後輩達に君の情熱を投げかけて欲しい。レーザー人口を一人でも増やすためにも.

* 東海大学工学部電気工学科 ( $25259-1292$ 神奈川県平塚市北金目1117)

* Department of Electrical Engineering Tokai University, 1117 Kitakaname, Hiratsuka, Kanagawa 259-1292 